\title{
Elemental characterization of superficial waters contaminated by an abandoned sulfide-mining area, through neutron activation analysis
}

\author{
By N. Canha ${ }^{1}$, M. C. Freitas ${ }^{1, *}$, I. Dionísio ${ }^{1}$, A. M. G. Pacheco² and H. M. Anawar ${ }^{1}$ \\ ${ }^{1}$ Instituto Tecnológico e Nuclear (ITN), URSN, E.N. 10, 2686-953 Sacavém, Portugal \\ 2 CERENA-IST, Technical University of Lisbon, Av. Rovisco Pais 1, 1049-001 Lisboa, Portugal
}

(Received November 30, 2009; accepted in revised form December 20, 2010)

\begin{abstract}
Abandoned mines / Iberian pyrite belt / Mine leachates / São Domingos mine / Water contamination / $k_{0}-I N A A$
\end{abstract}

Summary. In this work, superficial waters of two small rivers flowing in the São Domingos' abandoned mining area were analyzed in order to infer on soil-water transfer of the elements determined. Instrumental neutron activation analysis was used for elemental concentration assessment. The following elements were found at the $\mathrm{mgL}^{-1}$ level: As, Ba, $\mathrm{Co}, \mathrm{Cu}, \mathrm{Fe}, \mathrm{K}, \mathrm{Na}$ and $\mathrm{Zn}$. The dry-mass residues varied between $70 \mathrm{mg}$ and $1 \mathrm{~g}$ in $20-\mathrm{mL}$ volumes. High enrichment relative to soil was found for most elements. Good statistical associations between $\mathrm{Br}$ and $\mathrm{Na}$, between $\mathrm{Cr}$ and $\mathrm{Sc}$, and between $\mathrm{Ce}, \mathrm{Co}, \mathrm{Fe}, \mathrm{Yb}$, and $\mathrm{Zn}$, were found, suggesting a similar mechanism of soil-water, elemental transfer. Both the superficial waters' composition and their elemental levels indicate a potential risk of contamination of the underground waters and an actual health risk for the resident populations.

\section{Introduction}

Mining activities have negatively affected lands, waterbodies and ecosystems throughout the world [1]. Prior to environmental regulations came into force, mine tailings were left non-recultivated in the open landscape, or were often disposed of by simply dumping them into nearby streams and rivers [2]. This has led to some of the tailings being transferred to fluvial deposits in the floodplains along local tributaries and major river banks. Such deposits can be extremely acidic and contain large amounts of heavy metals and other toxic elements [2-5].

The former sulfide-mining complex of São Domingos is located at the Lower Alentejo area of southern Portugal, and was once a most significant operation within the Iberian pyrite belt. Average concentrations were $1.25 \%$ of copper, $2-3 \%$ of zinc, together with $45-48 \%$ of sulfur; sulfide minerals other than iron pyrite - such as chalcopyrite, galena, arsenopyrite and sulfosalts - were found as well. After its shut-down for depletion of the ore reserves, in 1966, the mine has never been properly decommissioned, and rather left to an effective abandon that has since caused an uncontrolled, continuing damage to local ecosystems, regional

\footnotetext{
*Author for correspondence (E-mail: cfreitas@itn.pt).
}

watersheds and the environment at large. Suffice it to say that more than $25 \mathrm{Mt}$ of ore were extracted, leaving some $750000 \mathrm{t}$ of mining waste and metallurgical debris dispersed around the former mine works [6], and up to a staggering $27 \mathrm{Mt}$ of leachable materials, should one consider all mine phases, including Gossan waste, country rocks and industrial landfill [7].

Leaching of mine tailings and soil by pluvial waters induces a negative impact at the São Domingos' local stream a small creek that flows to the Chança river - mainly due to its low $\mathrm{pH}(<3)$ and high conductivity. Therefore, the acid drainage from the mine-impacted area reaches not only the Chança river, but eventually finds its way into the Guadiana river, an international watercourse that opens into the Atlantic Ocean at southern Portugal (Algarve), forming part of the Portuguese-Spanish border, and for which the Chança is a major left-bank tributary.

In this work, surface waters were collected from the São Domingos creek and the Chança river, with the aim to determine element contents at different distances from the mine main well. The determination was carried out through long-time, instrumental neutron activation analysis (INAA; $k_{0}$-variant), which is an adequate methodology for liquid samples highly loaded with metals. Previously, a short-time mode of this technique has been applied to analyzing drinking water [8].

\section{Experimental}

Surface waters were collected in May 2009 at six sites within the general area impacted by mine tailings, dust mobilization and acidic drainage from the former São Domingos sulfide-mining complex - Fig. 1 .

Water samples were cleared using $0.45-\mu \mathrm{m}$ filters (Millipore ${ }^{\mathrm{TM}}$ ), stored in acid-washed bottles, and refrigerated at $4{ }^{\circ} \mathrm{C}$. After adjusting to $\mathrm{pH} \cong 2$ with $\mathrm{HNO}_{3}$, up to $1 \mathrm{~mL}$ each $2 \mathrm{~L}$ whenever originally higher (at a few sites, $\mathrm{pH}$ was close to zero), the water volumes were measured (around $20 \mathrm{~mL}$ ) and the samples were freeze-dried. Typical masses of the residues were in the range of $70 \mathrm{mg}$ to $1 \mathrm{~g}$, of which between $48 \mathrm{mg}$ and $120 \mathrm{mg}$ were then put into ultrapure polyethylene containers for irradiation and measurement.

Experimental (average) conditions were as follows: i) sample irradiation for $5 \mathrm{~h}$ at a thermal-neutron flux 


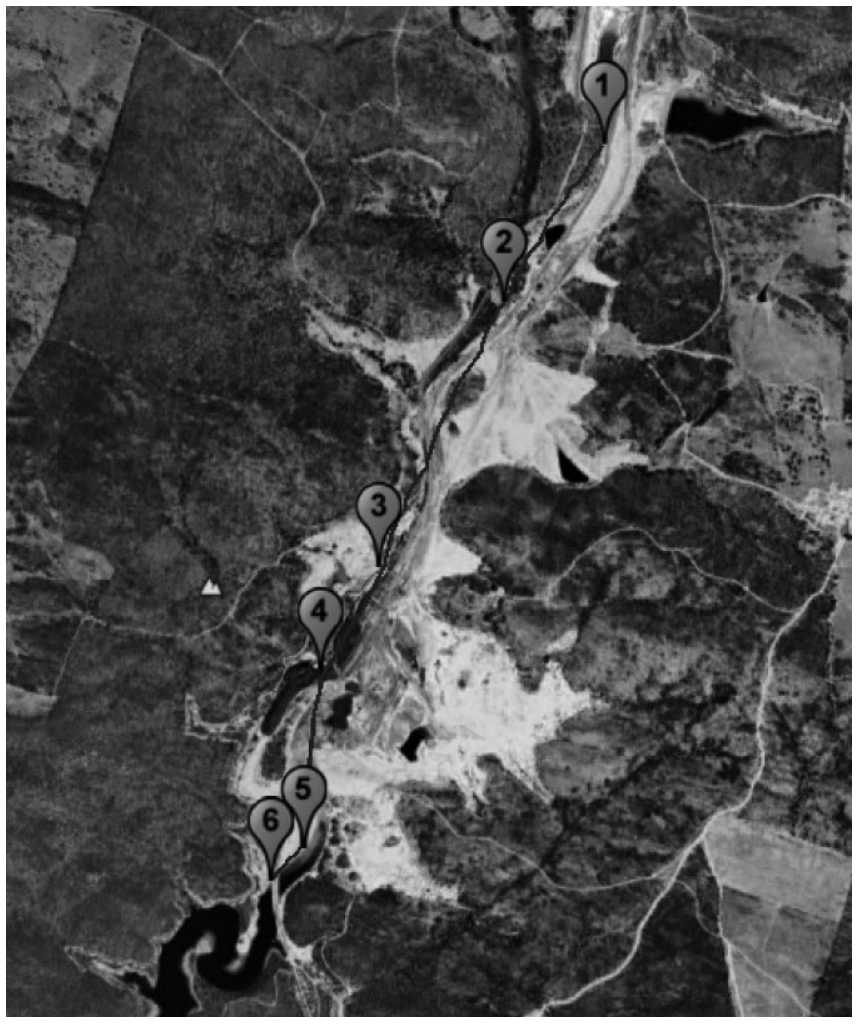

Fig. 1. Sampling locations (1-6) for surface waters along the São Domingos creek, in the mine-impacted area. Site 1 is at the main mine well, and sites $2-6$ are at $0.55 \mathrm{~km}, 1.4 \mathrm{~km}, 1.74 \mathrm{~km}, 2.25 \mathrm{~km}$ and $2.37 \mathrm{~km}$ from the main mine well, respectively.

of $2 \times 10^{12} \mathrm{~cm}^{-2} \mathrm{~s}^{-1}$, together with one disc (thickness: $125 \mu \mathrm{m}$; diameter: $5 \mathrm{~mm}$ ) of an Al-0.1\%Au alloy as comparator, in the Portuguese Research Reactor (RPI-ITN; pool-type reactor; maximum nominal power: $1 \mathrm{MW}$ ); ii) gamma-spectrometry measurement with an ORTEC ${ }^{\circledR}$, liquid $\mathrm{N}_{2}$-cooled, high-purity $\mathrm{Ge}$ detector $(1.85 \mathrm{keV}$ resolution at
$1.33 \mathrm{MeV} ; 30 \%$ relative efficiency), after $4 \mathrm{~d}$ and 4 weeks for the samples, and after one week for the comparator; iii) evaluation of element concentrations using the $k_{0}$-IAEA program (version 3.21). Blanks of ultrapure polyethylene containers were dealt with in the same way as the samples.

Additional details on irradiation conditions and reactor parameters for the current implementation of $k_{0}$-INAA at the RPI-ITN may be found elsewhere [9, 10]. Quality-assurance aspects for the $k_{0}$-methodology have already been discussed as well $[8,11]$. Comparison of elemental patterns in the samples has also been used as an a posteriori data validation.

\section{Results and discussion}

Table 1 lists the concentration results for the water samples, in $\mathrm{mg} \mathrm{L}^{-1}$. The following elements were found at the $\mathrm{mg} \mathrm{L}^{-1}$ level: $\mathrm{As}, \mathrm{Ba}, \mathrm{Co}, \mathrm{Cu}, \mathrm{Fe}, \mathrm{K}, \mathrm{Na}, \mathrm{Zn}$; the remainder were at the $\mu \mathrm{gL}^{-1}$ level. Only As, Br, Ce, Co, Fe, Na, Sc, Yb and $\mathrm{Zn}$ were above the detection limit (LOD) in all samples. Other elements with values below LOD at some of the sites were $\mathrm{Ba}, \mathrm{Cd}, \mathrm{Cr}, \mathrm{Cu}, \mathrm{Eu}, \mathrm{Hf}, \mathrm{K}, \mathrm{La}, \mathrm{Lu}, \mathrm{Mo}, \mathrm{Ta}, \mathrm{Tb}$ and Th. As reported by Freitas et al. [11], soils where these waters circulate showed ranges (all in $\mathrm{mg} \mathrm{kg}^{-1}$ ) of $448-3565$ for As, 1-9.7 for $\mathrm{Br}, 4.9-79.9$ for $\mathrm{Co}, 77.2-139.4$ for $\mathrm{Cr}$, 79280-186400 for Fe, 27.2-58.1 for La, 11.7-22.6 for Sc, and 178-4035 for Zn. Other (unreported) values are available as follows, also in $\mathrm{m} \mathrm{kg}^{-1}:<590-621$ for Ba, 51-116 for $\mathrm{Ce}, 476-3962$ for $\mathrm{Cu}, 0.4-1.7$ for $\mathrm{Eu}, 3.3-7.2$ for $\mathrm{Hf}$, 12 410-35030 for $\mathrm{K},<0.4-0.3$ for $\mathrm{Lu},<120-33$ for Mo, 2120-10 050 for $\mathrm{Na}, 0.4-1.4$ for $\mathrm{Ta},<0.9-0.4$ for $\mathrm{Tb}, 3.6-13$ for Th, and 1.3-2.3 for Yb. For Cd in soils, only LOD values were obtained (between $<15$ and $<82 \mathrm{mg} \mathrm{kg}^{-1}$ ).

Fig. 2 illustrates the enrichment factors (EFs) of elements in the waters relative to the soils where they flow. The normalizing (crustal-reference) element was Sc, since it can

Table 1. Elemental concentrations and their standard deviations (in $\mathrm{mg} \mathrm{L}^{-1}$ ) in superficial waters collected at the São Domingos mining area (6 sampling sites) on May 2009, determined by $k_{0}$-INAA. Number of replicates: 3 .

\begin{tabular}{|c|c|c|c|c|c|c|}
\hline Element & Site 1 & Site 2 & Site 3 & Site 4 & Site 5 & Site 6 \\
\hline As & $1.78 \pm 0.07$ & $0.51 \pm 0.03$ & $0.018 \pm 0.007$ & $0.0124 \pm 0.0005$ & $0.011 \pm 0.002$ & $0.006 \pm 0.002$ \\
\hline $\mathrm{Ba}$ & $1.7 \pm 0.8$ & $<6$ & $<3$ & $<14$ & $<2$ & $<0.9$ \\
\hline $\mathrm{Br}$ & $0.064 \pm 0.008$ & $0.15 \pm 0.01$ & $0.22 \pm 0.01$ & $0.157 \pm 0.009$ & $0.100 \pm 0.008$ & $0.061 \pm 0.005$ \\
\hline $\mathrm{Cd}$ & $0.4 \pm 0.2$ & $<0.3$ & $<0.4$ & $0.3 \pm 0.1$ & $<0.2$ & $<0.2$ \\
\hline $\mathrm{Ce}$ & $0.112 \pm 0.008$ & $0.12 \pm 0.01$ & $0.041 \pm 0.006$ & $0.56 \pm 0.04$ & $0.029 \pm 0.003$ & $0.018 \pm 0.003$ \\
\hline $\mathrm{Co}$ & $1.30 \pm 0.02$ & $1.54 \pm 0.03$ & $0.61 \pm 0.01$ & $9.1 \pm 0.1$ & $0.416 \pm 0.008$ & $0.224 \pm 0.004$ \\
\hline $\mathrm{Cr}$ & $0.11 \pm 0.02$ & $0.06 \pm 0.03$ & $0.07 \pm 0.02$ & $<0.2$ & $0.03 \pm 0.01$ & $<0.071$ \\
\hline $\mathrm{Cu}$ & $36 \pm 3$ & $<0.04$ & $17 \pm 6$ & $9 \pm 2$ & $<13$ & $<0.02$ \\
\hline $\mathrm{Eu}$ & $0.0033 \pm 0.0003$ & $<0.00076$ & $0.0007 \pm 0.0002$ & $0.015 \pm 0.002$ & $0.0004 \pm 0.0001$ & $0.00018 \pm 0.00006$ \\
\hline $\mathrm{Fe}$ & $240 \pm 6$ & $623 \pm 12$ & $44 \pm 2$ & $2755 \pm 47$ & $73 \pm 2$ & $36 \pm 2$ \\
\hline $\mathrm{Hf}$ & $<0.004$ & $0.006 \pm 0.003$ & $<0.008$ & $<0.02$ & $<0.002$ & $<0.001$ \\
\hline K & $<2$ & $<3$ & $4 \pm 2$ & $<3$ & $<2$ & $2.9 \pm 0.7$ \\
\hline $\mathrm{La}$ & $0.045 \pm 0.002$ & $<0.0052$ & $0.020 \pm 0.004$ & $0.329 \pm 0.009$ & $0.023 \pm 0.002$ & $0.012 \pm 0.001$ \\
\hline $\mathrm{Lu}$ & $0.0008 \pm 0.0003$ & $<0.0006$ & $<0.0007$ & $<0.003$ & $<0.0004$ & $<0.0003$ \\
\hline Mo & $<2$ & $3 \pm 1$ & $<5$ & $<4$ & $0.27 \pm 0.09$ & $<2$ \\
\hline $\mathrm{Na}$ & $38 \pm 2$ & $87 \pm 4$ & $117 \pm 6$ & $57 \pm 2$ & $58 \pm 3$ & $46 \pm 2$ \\
\hline $\mathrm{Sc}$ & $0.043 \pm 0.002$ & $0.0047 \pm 0.0007$ & $0.0144 \pm 0.0007$ & $0.015 \pm 0.004$ & $0.0084 \pm 0.0004$ & $0.0045 \pm 0.0002$ \\
\hline $\mathrm{Ta}$ & $<0.003$ & $<0.01$ & $0.003 \pm 0.001$ & $<0.01$ & $<0.001$ & $<0.001$ \\
\hline $\mathrm{Tb}$ & $0.0020 \pm 0.0008$ & $0.003 \pm 0001$ & $<0.003$ & $<0.002$ & $<0.002$ & $0.0007 \pm 0.0002$ \\
\hline Th & $0.003 \pm 0.001$ & $<0.002$ & $<0.002$ & $<0.002$ & $<0.002$ & $<0.002$ \\
\hline $\mathrm{Yb}$ & $0.00650 \pm 0.00006$ & $0.005 \pm 0.002$ & $0.003 \pm 0.001$ & $0.011 \pm 0.004$ & $0.0019 \pm 0.0009$ & $0.0012 \pm 0.0003$ \\
\hline $\mathrm{Zn}$ & $70 \pm 2$ & $78 \pm 2$ & $20.5 \pm 0.7$ & $632 \pm 18$ & $13.5 \pm 0.3$ & $7.0 \pm 0.2$ \\
\hline
\end{tabular}




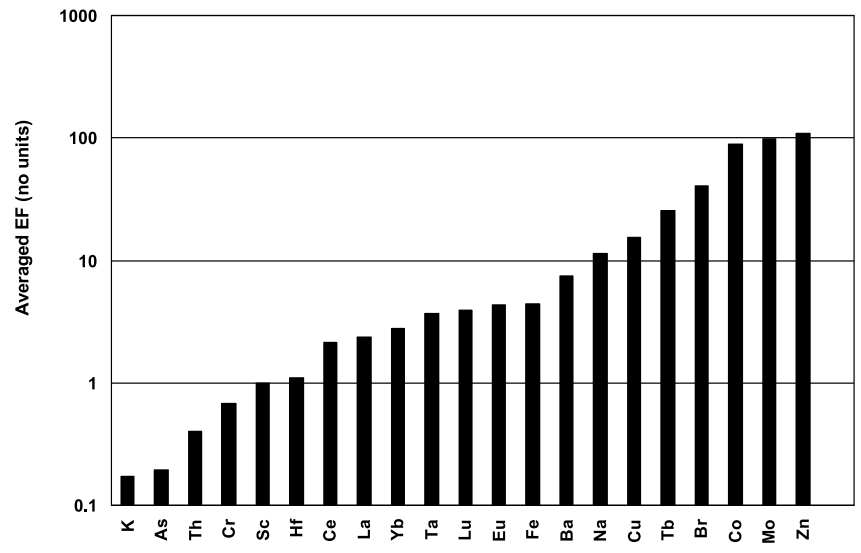

Fig. 2. Enrichment factors (EFs) of elements in surface waters (averaged over all sampling locations) relative to the mean soil composition of the mine-impacted area, using Sc as the crustal reference.

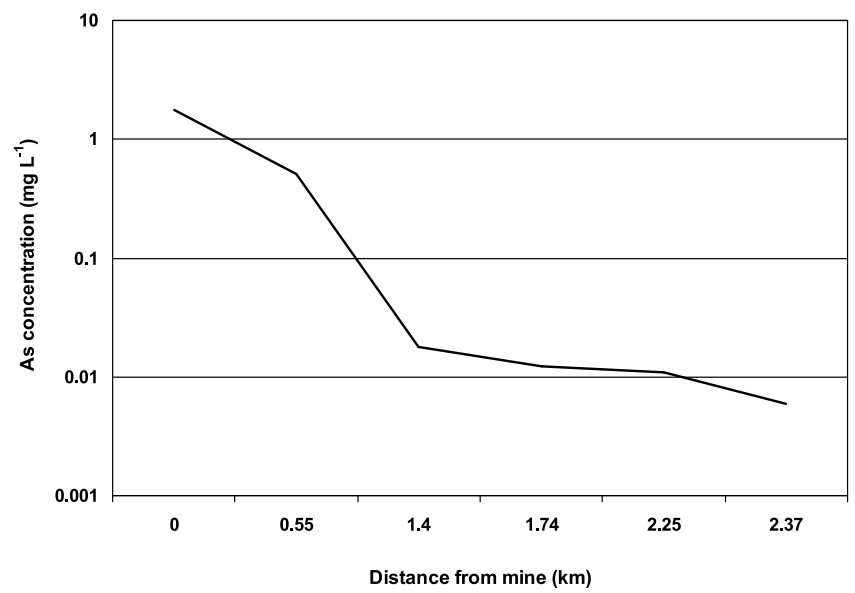

Fig. 3. Arsenic concentrations $\left(\mathrm{mg} \mathrm{L}^{-1}\right)$ in surface waters from the six sampling locations, as a function of the distance from the main mine well $(\mathrm{km})$.

only be originated in soil. The results may suggest the mechanisms of elemental transfer from soil to water. From this standpoint, the $\mathrm{EFs}<1$ indicate that there is a depletion of the elements K, As, Th and Cr relatively to their mean concentrations in soil, likely because these elements are not easily leached.

Fig. 3 shows how As concentration in water decreases with increasing distance from the mine. The drop in As levels is especially apparent (steeper) in the first $1.5 \mathrm{~km}$, roughly, and is in itself an indication of the contamination gradient around the mine shaft. Arsenic contamination in water is a global health concern due to its toxicity effects even at very low levels. The World Health Organization (WHO) has set the concentration limit for drinking water at $10 \mu \mathrm{g} \mathrm{L}{ }^{-1}$, meaning that only site 6 would nominally comply with such limit. Therefore, even if the waters did not dissolve much As from soil, its concentration is still high enough to exceed the safety limit for most of the studied area.

The elements $\mathrm{Sc}$ and $\mathrm{Hf}$ have $\mathrm{EF}=1$ and $\mathrm{EF} \approx 1$, respectively, the former definitely because it was taken as the crustal reference for the soil-normalization procedure, and the latter likely because its EF is based on a single value from site 2 (the others are below LOD). Fig. 4 illustrates the
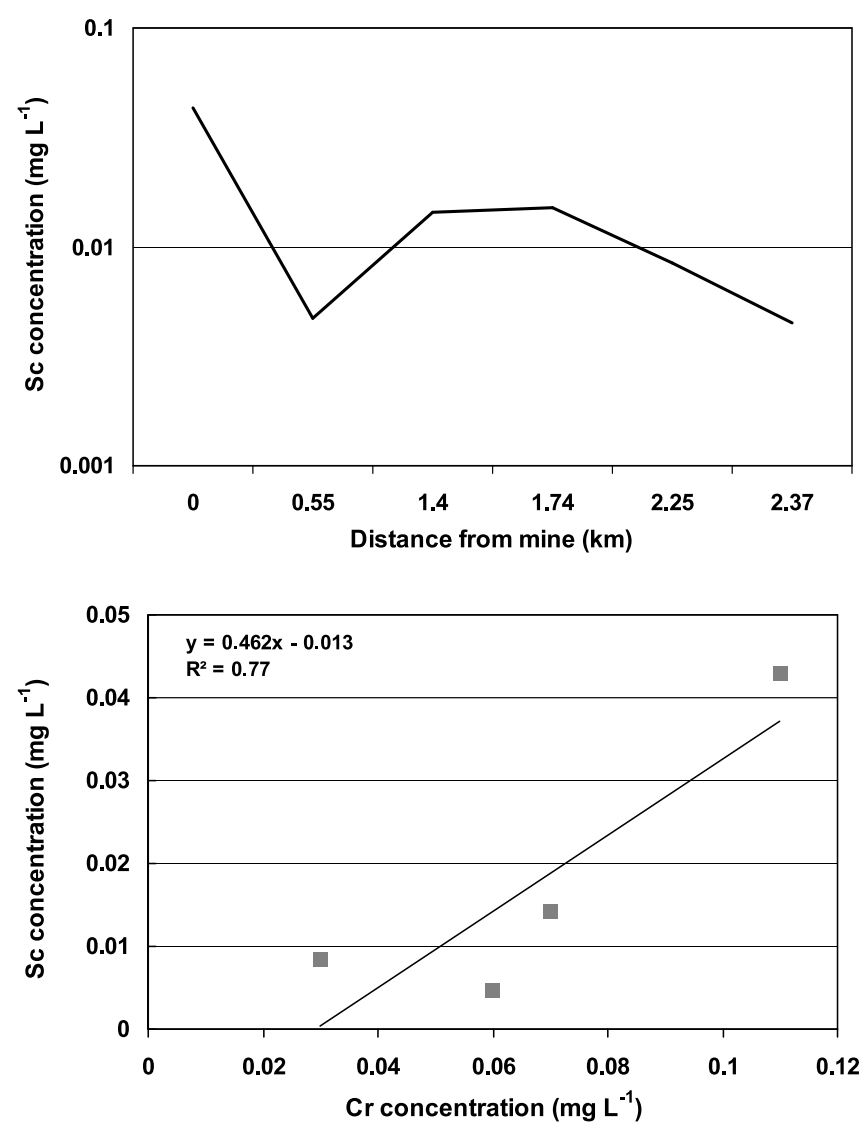

Fig. 4. Above: Scandium concentrations $\left(\mathrm{mg} \mathrm{L}^{-1}\right)$ in surface waters from the six sampling locations, as a function of the distance from the main mine well $(\mathrm{km})$. Below: Correlation between $\mathrm{Sc}$ and $\mathrm{Cr}$ concentrations $\left(\mathrm{mg} \mathrm{L}^{-1}\right)$.

spatial variation of Sc concentrations and their degree of association with $\mathrm{Cr}$ concentrations, which accounts for about $77 \%$ of the joint variability in the results. It should be noted that, in the sometimes extremely acidic conditions of São Domingos' waters, little precipitation (if any) of the elements herein should occur, except for trivalent chromium (and trivalent iron). As so, odds are that the chromium found in the sampled waters may be $\mathrm{Cr}^{6+}-\mathrm{a}$ well-known carcinogen - and not $\mathrm{Cr}^{3+}$. Obviously, this cannot be asserted without a proper speciation study and goes mentioned only as a hypothesis, albeit plausible.

The rare earth elements $(\mathrm{Ce}, \mathrm{La}, \mathrm{Eu}, \mathrm{Lu}, \mathrm{Yb}), \mathrm{Fe}$ and $\mathrm{Ba}$, with EFs between 1 and 10, appear moderately dissolved in the surface waters, while those with EFs between 10 and 100 $(\mathrm{Br}, \mathrm{Co}, \mathrm{Cu}, \mathrm{Mo}, \mathrm{Na}, \mathrm{Tb}, \mathrm{Zn})$ are easily transferred into the waters and become enriched in them. Fig. 5 depicts the good correlation between $\mathrm{Br}$ and $\mathrm{Na}$, that explains about $82 \%$ of the corresponding data variance. Even though volatile elements, such as $\mathrm{Br}$, can reach higher concentrations in surface waters [12], the present ratio $\mathrm{Na} / \mathrm{Br}$ is close to the average marine proportion for these elements [13], which may indicate an ancient use of sea salt in the former mine operation.

A few other elements also feature an identical spatial pattern as to the present conditions: $\mathrm{Ce}, \mathrm{Fe}$, and $\mathrm{Zn}$ (Fig. 6), plus $\mathrm{Co}$ and $\mathrm{Yb}$ (not shown). Interestingly enough, $\mathrm{Sc}$ in water does not follow this pattern (Fig. 4), which may be viewed as an a posteriori validation of the normalization procedure. In fact, and other than samples taken from the highly dis- 

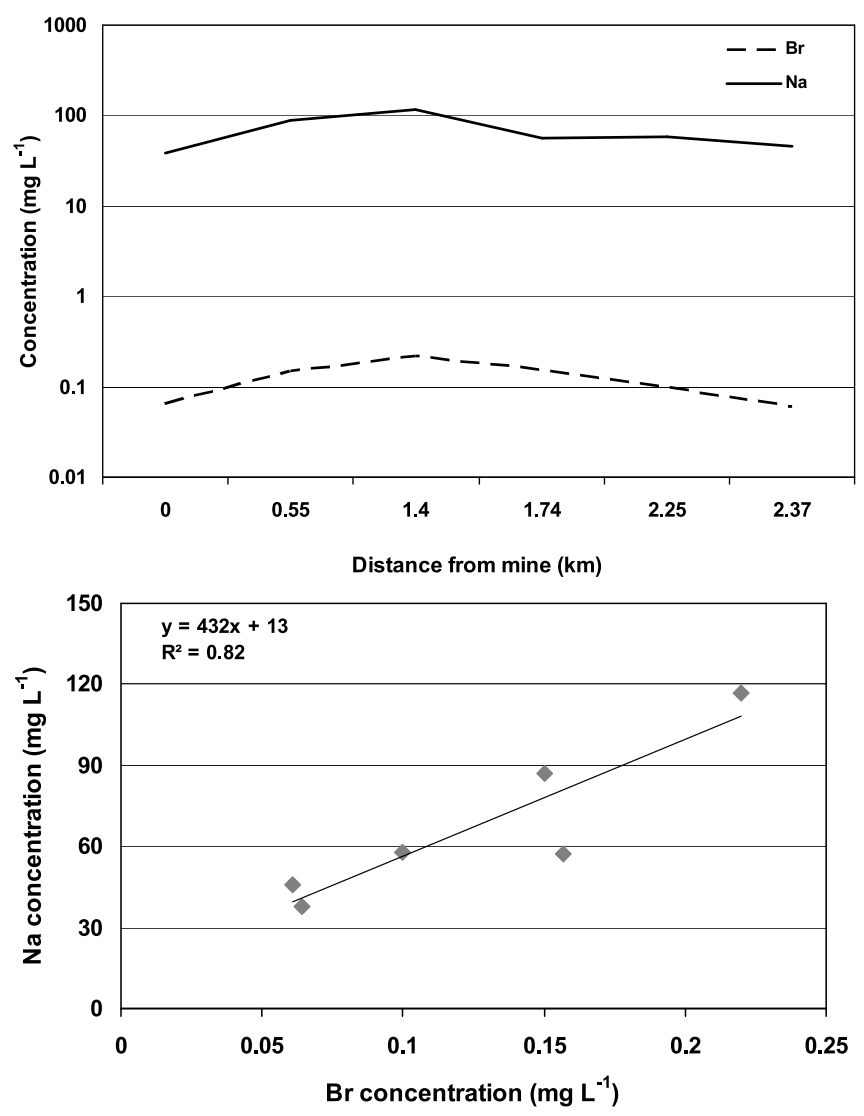

Fig. 5. Above: Bromine and sodium concentrations $\left(\mathrm{mg} \mathrm{L}^{-1}\right)$ in surface waters from the six sampling locations, as a function of the distance from the main mine well $(\mathrm{km})$. Below: Correlation between $\mathrm{Br}$ and $\mathrm{Na}$ concentrations $\left(\mathrm{mg} \mathrm{L}^{-1}\right)$.

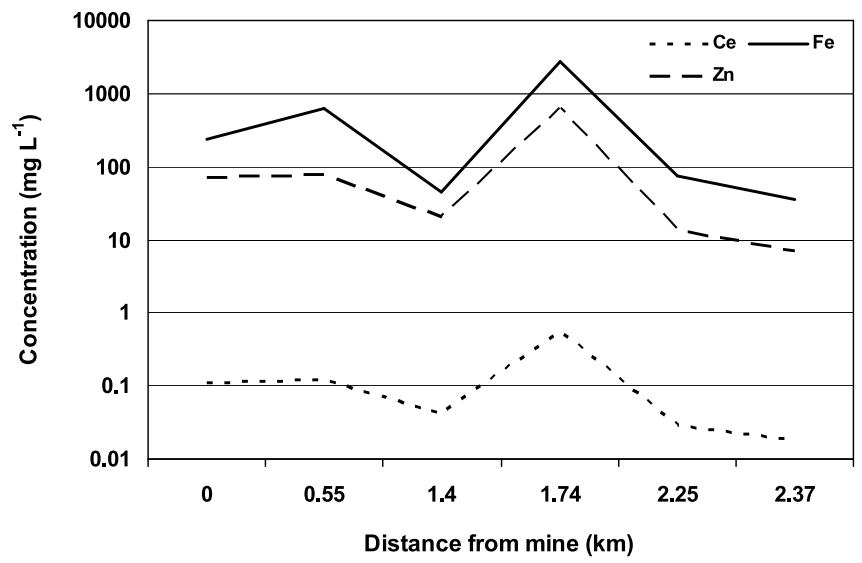

Fig. 6. Cerium, iron and zinc concentrations $\left(\mathrm{mg} \mathrm{L}^{-1}\right)$ in surface waters from the six sampling locations, as a function of the distance from the main mine well $(\mathrm{km})$.

turbed environment in close vicinity of the main well (site 1), Sc levels are relatively indifferent (unresponsive) to the sampling distance, and, therefore, the crustal origin of the element seems unquestionable. As for $\mathrm{Cd}$, the available results - around $0.4 \mathrm{mg} \mathrm{L}^{-1}$ - largely exceed the guideline value by WHO for safe drinking water, which is less than $1 \mu \mathrm{g} \mathrm{L}^{-1}$. Of course, Cd concentrations were above LOD for sites 1 and 4 only, which is not enough for any sound assessment of the variability in the results.

On the other hand, in acidic media $(\mathrm{pH}<3), \mathrm{Cd}, \mathrm{Co}, \mathrm{Cu}$ and $\mathrm{Zn}$ are highly prone to soil-water transfer, whereas most other metals are somewhat less mobile or even scarcely mobile. According to Fig. 2, Cu, Co and $\mathrm{Zn}$ - especially the last two - are well above the commonly accepted threshold for significant enrichment $(\mathrm{EF} \geq 10)$, which confirms their potential for mobilization from the soil to the aqueous phase. Other studies have corroborated this trend. For instance, the metal losses (in $\mathrm{g} \mathrm{ha}^{-1}$ year $^{-1}$ ) from topsoils at $\mathrm{pH}=2.9$ in forest ecosystems of West Germany were $2(\mathrm{Cr}), 12(\mathrm{Cd}), 55$ $(\mathrm{Co}), 68(\mathrm{Cu})$ and $221(\mathrm{Zn})$ [14]. It has also been reported that, at the low $\mathrm{pH}$ conditions currently found in mining environments, most metals are strongly combined with sulfate $\left(\mathrm{SO}_{4}{ }^{2-}\right)$ anions, that tend to be electrostatically bound to metal cations (namely, $\mathrm{Cu}, \mathrm{Fe}$ and $\mathrm{Zn}$ cations) and form stable ion pairs and complexes [14]. The same might as well have occurred here, but, then again, speciation would be needed to support this hypothesis.

The microbiology, microbial ecology and biogeochemistry of acidic mine waters in the Iberian pyrite belt have been addressed by several studies [15-20], and, in this respect, the São Domingos mine is no exception. An acidic and thixotropic mine pond, directly impacted by a tailings dump (Achada do Gamo), has been deemed of particular interest for its indigenous aquatic microflora [21]. Three distinct - and persistent, though relative counts may vary colony types of viable microorganisms: Leptospirillum ferrooxidans, "Ferrimicrobium" spp. and Acidithiobacillus ferrooxidans. These colonies are viable in such an extreme environment even if there is an on-going enrichment of metals and sulfate, to the extent that there appears to be a broad correlation between microbial numbers and solute concentration [21]. The self-feeding and releasing of the bio-available fraction at Achada do Gamo is just the tip of the iceberg though. In terms of bioavailability, and considering only the elements in the present study, the São Domingos wastes may leach up to about $172514 \mathrm{t}$ of Fe, $2610 \mathrm{t}$ of $\mathrm{Zn}, 1032 \mathrm{t}$ of $\mathrm{Cu}$, $183 \mathrm{t}$ of $\mathrm{Cr}, 109 \mathrm{t}$ of As and $0.9 \mathrm{t}$ of Cd [7], from an estimated $5 \mathrm{Mt}$ of mine tailings and mineral spoil directly related to the core operation of the abandoned mine [21].

\section{Conclusions}

This work has shown that INAA ( $k_{0}$-variant) is a suitable technique for analysis of mining water that usually yields a large amount of dry residue, which can easily be separated, e.g., by freeze-drying, and then used for assaying replicate samples. Two poisonous and carcinogenic elements - As and $\mathrm{Cd}$ - were found in surface waters sampled from the general area impacted by the abandoned São Domingos mine wastes, both at levels that exceed the WHO guidelines for human consumption. Good correlations were found between $\mathrm{Br}$ and $\mathrm{Na}$, in an average proportion that approaches their marine ratio, and between $\mathrm{Sc}$ and $\mathrm{Cr}$. A few elements - $\mathrm{Ce}, \mathrm{Co}, \mathrm{Fe}, \mathrm{Yb}, \mathrm{Zn}$ showed comparable spatial patterns through the sampling sites, and an overall assessment of EFs suggests similar mechanisms for elemental soil-water transfer. Speciation of these waters is required and intended to be performed in the near future, in order to identify the chemical forms and clarify the actual mechanisms of transfer. The potential harmful effect of these surface waters onto underground aquifers and regional watersheds 
must be studied to assess the real health risks for the resident population.

Acknowledgment. Financial support by Fundação para a Ciência e a Tecnologia (FCT; Portugal) through research contract PTDC/AMB/ $65462 / 2006$ - HYPERAS is gratefully acknowledged. One of the authors (H.M.A.) is indebted to FCT for his post-doctorate grant. The authors are also indebted to the anonymous Reviewers for their constructive remarks and helpful comments.

\section{References}

1. Plass, W. T.: History of surface mining reclamation and associated legislation. In: Reclamation of Drastically Disturbed Lands - Agronomy Monograph 41. (Barnhisel, R. I., Darmody, R. G., Daniels, W. L., eds.) American Society of Agronomy, Madison, WI, USA (2000).

2. Richmond, T.: The revegetation of metalliferous tailings. In: Reclamation of Drastically Disturbed Lands - Agronomy Monograph 41. (Barnhisel, R. I., Darmody, R. G., Daniels, W. L., eds.) American Society of Agronomy, Madison, WI, USA (2000).

3. Ross, S. M.: Toxic Metals in Soil-Plant Systems. John Wiley and Sons, Chichester, UK (1994).

4. Edwards, K. J., Gihring, T. M., Banfield, J. F.: Seasonal variations in microbial populations and environmental conditions in an extreme acid mine drainage environment. Appl. Environ. Microbiol. 65, 3627 (1999).

5. Druschel, G. K., Baker, B. J., Gihring, T. M., Banfield, J. F.: Acid mine drainage biogeochemistry at Iron Mountain, California. Geochem. Trans. 5, 13 (2004).

6. Freitas, H., Prasad, M. N. V., Pratas, J.: Plant community tolerant to trace elements growing on the degraded soils of São Domingos mine in the south east of Portugal: environmental implications. Environ. Int. 30, 65 (2004).

7. Pérez-López, R., Álvarez-Valero, A. M., Nieto, J. M., Sáez, R., Matos, J. X.: Use of sequential extraction procedure for assessing the environmental impact at regional scale of the São Domingos Mine (Iberian Pyrite Belt). Appl. Geochem. 23, 3452 (2008).

8. Freitas, M. C., Vieira, B. J., Pacheco, A. M. G.: Iodine levels in drinking water across rural counties adjoining a former uranium mining and milling works, through short-time activation analysis. Nucl. Instrum. Methods A 579, 514 (2007).

9. Pacheco, A. M. G., Freitas, M. C., Ventura, M. G., Dionísio, I., Ermakova, E.: Chemical elements in common vegetable compo- nents of Portuguese diets, determined by $k_{0}$-INAA. Nucl. Instrum. Methods A 564, 721 (2006).

10. Freitas, M. C., Pacheco, A. M. G., Dionísio, I., Sarmento, S., Baptista, M. S., Vasconcelos, M. T. S. D., Cabral, J .P.: Multianalytical determination of trace elements in atmospheric biomonitors by $k_{0-}$ INAA, ICP-MS and AAS. Nucl. Instrum. Methods A 564, 733 (2006).

11. Freitas, M. C., Pacheco, A. M. G., Anawar, H. M., Dionísio, I., Dung, H. M., Canha, N., Bettencourt, A., Henriques, F., PintoGomes, C. J., Capelo, S.: Determination of phytoextraction potential of plant species for toxic elements in soils of abandoned sulphide-mining areas. J. Radioanal. Nucl. Chem. 282, 21 (2009).

12. Kabata-Pendias, A., Pendias, H.: Trace Elements in Soils and Plants. $3^{\text {rd }}$ Edn., CRC Press LLC, Boca Raton, FL, USA (2001).

13. Bowen, H. J. M.: Environmental Chemistry of the Elements. Academic Press, London, UK (1979).

14. Mayer, R., Schultz, R.: Effect of soil acidification on heavy metal cycling in forest ecosystems. In: Heavy Metals in the Environment. Vol. 2 (Lindberg, S. E., Hutchinson, T. C., eds.) CEP Consultants Ltd., Edinburgh (UK) 1987.

15. López-Archilla, A. I., Amils, R.: A comparative ecological study of two acidic rivers in southwestern Spain. Microbial Ecol. 38, 146 (1999).

16. López-Archilla, A. I., Marin, I., Amils, R.: Microbial community composition and ecology of an acidic aquatic environment: the Tinto river, Spain. Microbial Ecol. 41, 20 (2001).

17. González-Toril, E., Llobet-Brossa, E., Casamayor, E. O., Amann, R., Amils, R.: Microbial ecology of an extreme acidic environment, the Tinto river. Appl. Environ. Microbiol. 69, 4853 (2003).

18. Aguilera, A., Manrubia, S. C., Gómez, F., Rodríguez, N., Amils, R.: Eukaryotic community distribution and its relationship to water physicochemical parameters in an extreme acidic environment, Río Tinto (southwestern Spain). Appl. Environ. Microbiol. 72, 5325 (2006).

19. España, J. S., González-Toril, E., Pamo, E. L., Amils, R., Ercilla, M. D., Pastor, E. S., San Martín-Úriz, P.: Biogeochemistry of a hyperacidic and ultraconcentrated pyrite leachate in San Telmo mine (Iberian pyrite belt, Spain). Water Air Soil Pollut. 194, 243 (2008).

20. González-Toril, E., Aguilera, A., Rodriguez, N., Fernández-Remolar, D., Gómez, F., Diaz, E., García-Moyano, A., Sanz, J. L., Amils, R.: Microbial ecology of Río Tinto, a natural extreme acidic environment of biohydrometallurgical interest. Hydrometallurgy 104, 329 (2010).

21. Johnson, D. B.: Biohydrometallurgy and the environment: intimate and important interplay. Hydrometallurgy 83, 153 (2006). 